\title{
geografin
} Malaysian Journal of Society and Space

\section{Analisis tahap penerimaan isu Melayu-Islam dalam kempen pilihan raya di kawasan Melayu pinggir bandar}

\author{
Marzudi Md Yunus ${ }^{1}$, Mohd Mahadee Ismail², Azlina Abdullah ${ }^{3}$, Nor Azlili Hassan ${ }^{4}$, Hairol Anuar \\ Mak $\operatorname{Din}^{5}$ \\ ${ }^{1}$ Jabatan Sosio-Budaya/Kesenian Melayu, Akademi Pengajian Melayu, Universiti Malaya \\ ${ }^{2}$ Jabatan Pengajian Kenegaraan dan Ketamadunan, Fakulti Ekologi Manusia, Universiti Putra \\ Malaysia \\ ${ }^{3}$ Program Antropologi dan Sosiologi, Pusat kajian Pembangunan Sosial dan Persekitaran, \\ Fakulti Sains Sosial dan Kemanusiaan, Universiti Kebangsaan Malaysia \\ ${ }^{4}$ Jabatan Pengajian Umum, Fakulti Industri Kreatif, Universiti Tunku Abdul Rahman \\ ${ }^{5}$ Pusat Pengajian Siswazah, Kolej Universiti Islam Selangor
}

Correspondence: Marzudi Md Yunus (email: marzudi@um.edu.my)

Received: 27 March 2020; Accepted: 06 June 2020; Published: 29 November 2020

\begin{abstract}
Abstrak
Pilihan raya adalah medan penyampaian maklumat atau membangkitkan isu yang boleh digunakan oleh parti politik yang bertanding dalam pilihan raya. Dalam proses menyakinkan pengundi, parti politk dan calon akan menggunakan pelbagai strategi yang boleh menarik minat pengundi supaya mengundi mereka. Isu yang dekat dihati dan diterima oleh pengundi akan mendorong mereka memilih atau menolak calon yang bertanding. Isu-isu dalam suatu pilihan raya sangat penting untuk diurus dan dimanipulasi oleh parti politik. Penerimaan pengundi terhadap suatu isu akan membuka peluang kepada calon yang bertanding untuk menang. Kajian ini menganlisis isu-isu yang digunakan oleh parti politik bagi meraih sokongan pengundi Melayu di pinggir bandar. Isu Melayu-Islam, ekonomi, 1MDB, dan kedaulatan raja-raja antara isu yang penting bagi pengundi Melayu. Kajian ini bertujuan mengenal pasti tahap kedudukan penerimaan isu Melayu-Islam dalam kalangan pengundi Melayu. Seterusnya kajian ini menganalisis penerimaan isu berasaskan umur, taraf pendidikan dan perolehan pendapatan dengan menggunakan kaedah kuantitatif. Responden kajian ini terdiri daripada pengundi Melayu di Dewan Undangan Negeri Semenyih yang dipilih secara rawak mudah. Dapatan yang diperolehi melalui kajian ini menunjukkan bahawa isu-isu Melayu-Islam secara dasarnya menarik minat pengundi Melayu dalam sesuatu kempen pilihan raya. Bagaimanapun tahap penerimaan tersebut adalah berasaskan kepada pemboleh ubah seperti umur, tahap pendidikan dan juga ekonomi seseorang. Sudut pandang berbeza berasaskan latar belakang individu akan mengubah kedudukan tahap penerimaan suatu isu dalam kempen pilihan raya.
\end{abstract}

Kata kunci: isu, kempen, pilihan raya, politik, Melayu, Islam 


\title{
Analysis of acceptance of Malay-Islamic issue in the election campaign in the Malay area suburbs
}

\begin{abstract}
Election is a venue for information disemination or for raising issues by any political party partaking in the election campaign. In the process of convincing the voters, the political party will use a variety of strategies to attract the voters. The issue close to voters will drive them to choose or reject the candidate. The issues in an election are very important for the political party to control and manipulate. This study analyse issues used by political parties to gain the support of Malay voters in the suburb. Malay-Muslim issues, the economy, 1MDB, and the rule of kings of an important issue. This study aims to identify the position of the MalayMuslim acceptance of the issue among Malay voters. This study then analyzes the acceptance of issues based on age, education and income using quantitative methods. Respondents selected for this are Malay voters in Semenyih. The findings show that the issues of MalayMuslim basically attract the Malay voters in a campaign. However, the level of acceptance is based on variables such as one's age, education level and economic status. Different viewpoints will change the level of acceptance of an issue in an election campaign.
\end{abstract}

Keywords: issues, campaign, election, politic, Malay, Islam

\section{Pengenalan}

Kempen pilihan raya ialah proses bagi parti politik dan calon yang bertanding cuba meyakinkan pengundi supaya mengundi mereka. Dalam proses tersebut, calon dan parti politk akan menggunakan pelbagai strategi yang boleh menarik minat pengundi. Isu yang dekat dihati pengundi akan mendorong mereka memilih atau menolak calon yang bertanding. Isu-isu dalam pilihan raya sangat penting untuk diurus dan dimanipulasi oleh parti politik. Malaysia mengamalkan sistem pilihan raya yang berteraskan tiga prinsip utama, iaitu pertama, berasaskan undi majoriti mengikut kaedah First Past The Post System, calon yang menang adalah calon yang memperoleh undi terbanyak walaupun hanya mendapat kelebihan satu undi mengatasi calon lawannya yang lain; kedua, berasaskan pemilihan seorang perwakilan mengikut bahagian pilihan raya sama ada bahagian pilihan raya Parlimen atau bahagian pilihan raya Negeri (Single Member Territorial Representation); dan ketiga, berasaskan sistem penyertaan pelbagai parti politik dan pihak yang layak bertanding dalam sesuatu pilihan raya (Multi Party Electoral System) (SPR, 2007).

Bagi memenangi pilihan raya, isu yang menjadi bahan kempen penting bagi mempengaruhi pilihan pengundi. Isu merupakan nadi penggerak kempen dalam suatu pilihan raya. Pengurusan isu yang berkesan dan bertepatan pada situasi dan konteks memberi kelebihan kepada sesuatu parti yang bertanding memenagi pilihan raya (Suhaimee, 2008). Justeru, boleh disimpulkan bahawa, pemilihan isu yang sesuai merupakan strategi penting bagi membolehkan sesebuah parti memenangi pilihan raya yang ditandingi mereka.

Pilihan raya merupakan medan pertembungan isu nasional dan isu tempatan. Kemampuan setiap parti politik yang bertanding untuk memenangi kerusi yang dipertandingkan adalah bergantung kepada penerimaan isu yang dibawa mereka, akan diterima oleh rakyat. Pola pengundian dalam pilihan raya didasari oleh kemampuan jentera kempen membentuk persepsi terhadap sesuatu isu yang bersifat manipulatif (Mohd Azri et al., 2016). Ini bermakna, selain daripada kecenderungan pengundi terhadap parti politik 
tertentu, isu-isu yang dibawa semasa kempen pilihan raya mestilah mampu mengubah peluang suatu parti yang bertanding. (Muhammad Hazim et al., 2016). Fenomena ini menunjukkan bahawa suatu isu dalam pilihan raya penting dalam menentukan kemenangan sesebuah parti politik.

Aspek etnisiti merupakan perkara penting dan perlu diperhalusi oleh sesebuah parti politik di Malaysia kerana polarisasi pengundian mengikut etnik merupakan suatu elemen yang tidak boleh dikesampingkan. Setiap etnik di Malaysia mempunyai kecenderungan terhadap isu-isu tertentu secara khusus. Sesuatu isu mungkin tidak mendapat perhatian bagi sesuatu etnik, tetapi memberi kesan terhadap etnik lain (Junaidi et. al, 2012a). Fenomena ini memberikan tafsiran bahawa isu yang berkait dengan entik tertentu akan memberikan kesan dan boleh mempengaruhi kecenderungan sesuatu etnik untuk memilih sesebuah parti politik semasa pilihan raya.

Dalam kajian konteks ini, takrifan Melayu merujuk kepada Perkara 160 (2) Perlembagaan Persekutuan. Melayu merupakan etnik terbesar di Malaysia, untuk mendapat kemenangan besar dalam pilihan raya mestilah melibatkan sokongan etnik ini secara keseluruhannya. Dalam masyarakat Melayu, Islam telah menjadi satu pancang kepada kebudayaan, iaitu setiap elemen yang tidak menghubungkan dengan Islam tidak diterima oleh mereka (Solahuddin, 2016). Kegagalan memahami kecenderungan orang Melayu menyebabkan sesebuah parti itu ditolak oleh orang Melayu (Muhammad Hazim et al., 2016). Justeru adalah sangat kritikal bagi sesebuah parti politik memahami kecenderungan dan minat orang Melayu. Parti politik perlu mengenal pasti apakah isu-isu menarik minat orang Melayu yang memotivasikan mereka supaya memilih sesebuah parti politik yang memperjuangkan suatu isu yang dikaitkan dengan Melayu. Jadi kajian ini bertujuan menganalisis kecenderungan orang Melayu terhadap sesuatu isu yang dikaitkan dengan Melayu.

\section{Kajian literatur}

Manipulasi isu merupakan strategi yang ampuh bagi menarik sokongan pengundi. Isu-isu utama yang dimainkan adalah berbentuk kritikan negatif terhadap parti lawan, tawaran perkhidmatan terbaik sekiranya memenangi pilihan raya, melalui janji dalam manifesto dan bukti kejayaan dalam pentadbiran terdahulu di peringkat persekutuan atau negeri yang dikuasai masing-masing. Perkara-perkara ini dilaungkan di setiap kempen pilihan raya bagi membina keyakinan pengundi bahawa mereka adalah pilihan terbaik berbanding lawan masing-masing (Asmadi et al., 2019).

Shamsudin (2010) menjelaskan bahawa adalah sukar bagi sesuatu pihak mendominasi sesuatu maklumat yang hendak disampaikan kepada orang ramai. Maklumat yang menjadi isu politik ada kala perlu bersaing dengan maklumat lain seperti hiburan, sukan dan lain-lain untuk mendapatkan perhatian pengundi. Bagaimanapun pada masa kini peranan media massa dapat dimainkan oleh laman web dikatakan dapat menyampaikan maklumat yang diperlukan individu jika ia disusun dan menggunakan format reka bentuk yang sesuai (Colemen et al., 2008). Maklumat di media massa berupaya membangkitkan perhatian awam untuk dikupas oleh orang ramai. Graber (2003) menjelaskan bahawa media dan demokrasi hanyalah satu mitos, kerana budaya politik itu lebih penting daripada kebijaksanaan warga dan media yang cemerlang.

Shamsudin (2010) menjelskan, isu penting seperti kenaikan harga minyak dunia sejak 2006 terus memberi impak kepada pelbagai kos perkhidmatan dan makanan yang secara langsung dan tidak langsung. Golongan berpendapatan rendah merasa kenaikan harga barangan begitu membebankan kehidupan harian mereka. Bagi meyakinkan pengundi, 
Pakatan Rakyat semasa kempen PRU-12 telah menjanjikan pelbagai perkara semata-mata untuk memenuhi 'immediate gratifications' dalam kalangan pengundi seperti menurunkan harga minyak dan menjanjikan imbuhan tahunan daripada kerajaan. Isu keboleh dapatan pekerjaan, kesamarataan antara kaum, isu rasuah dan peningkatan kadar jenayah mempengaruhi keputusan rakyat mengundi dalam pilihan raya. Kenaikan harga barang telah menjejaskan kedudukan kewangan setiap pengundi. Kajian yang dibuat menunjukkan bahawa lebih daripada $80 \%$ menganggap isu kenaikan harga adalah penting dalam pilihan raya.

Mohd Azri et al. (2016) pula menjelaskan bahawa keperihatinan isu kepada masyarakat Melayu, adalah berkisar mengenai kemampuan calon dari segi pelaksanaan manifesto dan program pembangunan yang akan dilaksanakan. Selain itu, faktor kewibawaan pemimpin, pengawalan terhadap isu dan integriti adalah elemen yang menjadi pertimbangan pengundi. Semasa PRK DUN Sg. Limau, isu yang dominan ialah isu ekonomi dan kos sara hidup. Masyarakat di DUN Sg. Limau ialah golongan yang terlibat dalam sektor pertanian dan kerja-kerja kampung. Isu ini dimainkan oleh parti PAS bagi mendapat sokongan pengundi terhadap parti tersebut.

Isu pembangunan dalam sosio-ekonomi merupakan perkara penting dalam pilihan raya. Kemudahan infrastruktur seperti bangunan, jalan raya, jambatan dan kemudahan awam merupakan penanda aras utama yang merujuk kepada sesuatu pembangunan. Oleh itu, parti yang memeritah akan terus menggunakan isu pembangunan sebagai strategi kempen politik secara berterusan untuk memancing undi di kawasan luar bandar dan ini menyebabkan pengundi di kawasan luar bandar terus menyokong parti tersebut dalam setiap pilihan raya (Junaidi et al., 2012b).

Semasa PRU14, isu tempatan, nasional dan antarabangsa dalam sekelip mata boleh tular sampai kepada pengetahuan rakyat dengan pantas sekali. Kerajaan hampir mustahil mampu mengawal dan membendung semua penularan isu-isu politik dimedia sosial. Ratarata kefahaman dan persepsi rakyat telah terbentuk menerusi apa yang disampaikan oleh media yang dapat diakses oleh pengundi dengan mudah. Isu berkaitan dengan kleptokrasi, GST, 1MDB, negara Malaysia telah dijual kepada China dengan menggadaikan projek-projek mega yang diperoleh oleh konglomerat dari China, BR1M sebagai dedak, dan subsidi harga petrol menjadi isu yang menarik minat masyarakat (Lee et al., 2018).

Secara jelasnya boleh ditafsirkan bahawa manipulasi dan bagaimana penyebaran isu merupakan strategi penting untuk mendapatkan sokongan pengundi dalam suatu pilihan raya. Pihak yang dapat menyampaikan isu mempunyai satu langkah kehadapan dalam meraih sokongan. Bagaimanapun, isu-isu yang ditimbulkan tidak semuanya boleh menarik minat pengundi. Ada ketikanya sesuatu isu tidak mendapat sambutan pengundi berasaskan sosiobudaya pengundi di suatu tempat.

\section{Metodologi}

Kajian ini telah menggunakan kaedah kuantitatif bagi mendapat data penyelidikan ini. Responden kajian terdiri daripada pengundi di Dewan Undangan Negeri Semenyih. Kaedah pensampelan bagi mendapatkan responden adalah menggunakan pensampelan bukan rawak, yang mana responden diambil daripada pelbagai lokasi dalam DUN Semenyih seperti Desa Mahkota, Bandar Bukit Mahkota, Bandar Rinching, dan Sesapan Kelubi. Seramai 300 responden diberikan soalan soal selidik bagi mendapatkan maklum balas daripada mereka. Dapatan daripada data soal selidik dianalisis menggunakan perisian Statistical Package for the Social Sciences (SPSS). 


\section{Hasil kajian}

\section{Profil Responden}

Responden kajian ini terdiri daripada 300 orang, terdiri daripada pengundi yang tinggal di Desa Mahkota, Bukit Mahkota, Rinching, dan Sesapan Kelubi. Mereka terdiri daripada 63.0\% lelaki dan 37.0\% wanita. Peratusan umur pula terdiri daripada 3\% berumur 25-30 tahun, $58.3 \%$ berumur $31-40$ tahun, $25.3 \%$ berumur $41-50$ tahun, $6.6 \%$ berumur $51-60$ tahun, 5.5\% 61-70 tahun dan 0.9\% berumur 71-84 tahun. Pembahagian responden mengikut pendapatan pula terdiri daripada $42.3 \%$ berpendapatan RM1000-RM3000, 29.3\% berpendapatan RM3001-RM5000, 9.1\% berpendapatan RM5001-RM8000 dan terdapat $19.3 \%$ responden yang tidak menyatakan pendapatan mereka. Manakala pecahan mengikut tahap pendidikan responden pula ialah $16.7 \%$ tidak mempunyai sebarang kelulusan akademik, $1.3 \%$ mempunyai SRP/PMR sahaja, 21.0\% memiliki sijil kemahiran, 8.7\% memiliki diploma, $41.0 \%$ memiliki ijazah dan $4.7 \%$ memiliki ijazah tinggi, manakala terdapat $3.3 \%$ responden tidak menyatakan tahap pendidikan mereka.

\section{Isu-isu pilihan raya dominan bagi pengundi Melayu}

Secara amnya terdapat banyak isu nasional dan isu domestik digunakan bagi mendapat perhatian pengundi. Bagaimanapun kajian telah mengenal pasti sepuluh isu yang dominan dengan orang Melayu. Sepuluh isu tersebut merangkumi isu yang bersifat umum dan juga isu yang berkaitan dengan dengan perkara yang bersifat khusus, menjurus kepada Melayu-Islam. Isu yang bersifat umum merangkumi kenaikan kos sara hidup, urus tadbir negara, kenaikan kos bahan api, dan 1MDB. Manakala isu yang menjurus kepada isu Melayu-Islam ialah keistimewaan orang Melayu, kedaulatan Islam, pengukuhan Melayu, penarikan balik subsidi mengerjakan haji, kemuliaan raja-raja dan kejatuhan harga komoditi getah dan sawit (Shamsudin, 2010; Mohd Azri et al., 2016; Lee et al., 2018; Wan Ahmad, 2017). Dalam kajian ini, setiap responden diminta untuk memberikan markah skor bagi setiap isu yang dicadangkan. Nilai markah yang disediakan ialah bermula dari nilai [1] hingga nilai [10]. Nilai [1] merujuk kepada pilihan yang paling rendah, [5] pada tahap sederhana, manakala nilai [10] merujuk kepada pilihan yang paling tinggi.

Hasil analisis, iaitu pada Jadual 1 telah menunjukkan bahawa isu kenaikan kos sara hdup mendapat tempat pertama bagi isu yang menarik perhatian orang Melayu dengan perolehan nilai skor tertinggi sebanyak 2826 mata dengan min nilai skor 9.42 mata. Dapatan ini menunjukkan bahawa isu sejagat yang melibatkan ekonomi secara keseluruhannya turut mendapat perhatian orang Melayu. Isu yang kedua penting bagi orang Melayu ialah melibatkan keistimewaan orang Melayu dengan perolehan mata sebanyak 2799 dengan min nilai skor 9.33 mata. Dapatan ini menunjukkan bahawa orang Melayu masih lagi menganggap bahawa mereka mestilah diberikan hak keistimewaan sebagai penduduk asal di negara ini. Peminggiran orang Melayu dalam arus pemodenan akan memberi kesan terhadap hubungan antara etnik di Malaysia dalam konteks hubungan majoriti-minoriti (Hasnah, 2009). Perkara yang ketiga mendapat perhatian orang Melayu ialah kedaulatan Islam. Isu Islam ini mendapat nilai skor sebanyak 2785 mata dengan min nilai skor 9.29. Hal ini membuktikan bahawa Melayu dan Islam adalah dua perkara yang saling berkaitan di negara ini. Apabila membicarakan tentang Melayu, Islam akan turut sama dikaitkan secara langsung, kerana pembentukan jati diri dan kebudayaan Melayu itu sendiri saling melengkapi (Ahmad Munawar et al., 2012). Tempat keempat pula ialah melibatkan isu-isu pengukuhan Melayu. Isu pengukuhan Melayu juga mempunyai kaitan dengan penyatuan Melayu yang merentasi sempadan ideologi politik. Perkara ini semakin mendapat perhatian orang Melayu apatah lagi 
setelah pepecahan dominasi politik Melayu dalam kerajaan. Kuasa politik Melayu dikatakan kian longgar berikutan tertubuhnya PAS akibat keluarnya pemimpin daripada Biro Agama UMNO pada tahun 1951 (Ismail, 2008). Kemudian pada tahun 1988 berlaku pula perpecahan dengan penubuhan parti Semangat 46 yang memperjuangkan agenda Melayu yang asal (Mohd Faidz et al., 2011). Seterusnya krisis politik UMNO pada tahun 1988 telah membawa penubuhan parti Keadilan Nasional, pada tahun 1999 (Ku Hasnan et al., 2012). Terbaharu, perpecahan dalam UMNO berlaku pada tahun 2017 dengan tertubuhnya parti Pribumi Bersatu Malaysia (PPBM, 2017). Manakala, PAS juga tidak terkecuali menghadapi perpecahan dalaman. Penubuhan parti Amanah menunjukkan bahawa kuasa politik Melayu semakin terancam (Amanah, 2017).

Isu yang kelima mendapat perhatian orang Melayu ialah isu berkaitan urus tadbir negara. Isu ini mendapat nilai skor sebanyak 2647 mata dengan min nilai skor 8.77, keadaan ini menunjukkan bahawa orang Melayu sebenarnya prihatin dengan perkara yang melibatkan urus tadbir negara (Lee et al., 2018). Mereka sebenanya ingin melihat sistem urus tadbir yang bersifat kondusif terhadap budaya Melayu dengan berteraskan prinsip Islam secara menyeluruh (Rabiatul et al., 2019). Isu yang keenam ialah penarikan subsidi yang telah diberikan oleh kerajaan. Dalam konteks ini penarikan subsidi melibatkan tol, kenaikan menunaikan haji, bahan api dan tenaga (air dan elektrik). Isu ini mendapat skor sebanyak 2596 mata dengan min nilai skor 8.65. Nilai min ini masih lagi tinggi iaitu melepasi nilai min 5.0 (sederhana). Maka boleh dikatakan bahawa isu ini menarik minat orang Melayu kerana kesan penarikan subsidi oleh kerajaan boleh meningkatkan kos sara hidup mereka. Secara tidak langsung isu ini mempunyai kaitan dengan isu kenaikan kos sara hidup. Lebih-lebih lagi isu penarikan subsidi mengerjakan ibadat haji merupakan isu yang sensitif kepada orang Melayu (Asyraf, 2019). Kenaikan harga bahan api mendapat jumlah skor sebanyak 2564 mata dengan nilai min 9.55 menjadikan isu ini berada pada tahap ketujuh. Bahan api merupakan barangan keperluan harian yang sangat penting, sama pentingnya dengan barangan makanan. Pengguna memerlukan bahan api untuk membolehkan kenderaan berfungsi bagi tujuan pengangkutan. Kenaikan kos bahan api secara drastik memberi impak yang negatif terhadap rantaian barangan dan perkhidmatan pengguna (Abu Sufian, 2018).

Bagi orang Melayu, kemuliaan raja-raja Melayu mesti dipertahankan. Raja Melayu merupakan simbol ketuanan Melayu di tanah air sendiri. Institusi raja mempunyai pengaruh dan sejarah yang panjang terhadap orang Melayu (Mohd Shazwan et al., 2019). Bagaimanapun berdasarkan Jadual 1, didapati isu yang berkaitan dengan kemuliaan raja-raja berada pada tahap kelapan dengan skor sebanyak 2304 dengan min nilai skor 7.68 , secara tidak langsung menunjukkan bahawa orang Melayu pada masa kini lebih mementingkan perkara yang melibatkan kepentingan peribadi mereka terlebih dahulu sebelum melihat kelangsungan institusi raja-raja Melayu itu sebagai keutamaan. Seterusnya isu 1MDB mendapat skor sebanyak 2267 dengan min nilai skor 7.56, walaupun berada pada tahap yang sederhana tinggi. Isu ini merupakan isu yang telah menggugat kuasa politik dan memberi impak yang cukup besar terhadap UMNO, iaitu menjadi faktor kepada kekalahan Barisan Nasional dalam Pilihan Raya Umum ke-14 (Muhamad Nadzri \& Noorjamaie, 2018). Akhir sekali, iaitu isu yang kesepuluh, kejatuhan harga komoditi pertanian mendapat jumlah skor sebanyak 1788 dengan min nilai skor 5.96 sahaja. 
Jadual 1. Nilai skor isu-isu yang dominan dalam kempen PRK DUN Semenyih 2019

\begin{tabular}{llcc}
\hline Bil & Perkara & Nilai skor & Nilai skor Min \\
\hline 1 & Kenaikan kos sara hidup & 2826 & 9.42 \\
2 & Keistimewaan Melayu & 2799 & 9.33 \\
3 & Kedaulatan Islam & 2785 & 9.29 \\
4 & Pengukuhan Melayu & 2647 & 8.82 \\
5 & Isu urus tadbir negara & 2631 & 8.77 \\
6 & Tarik subsidi & 2596 & 8.65 \\
7 & Kenaikan kos bahan api & 2564 & 8.55 \\
8 & Kemuliaan raja-raja & 2304 & 7.68 \\
9 & Isu 1MDB & 2267 & 7.56 \\
10 & Kejatuhan harga komoditi pertanian & 1788 & 5.96 \\
\hline $\mathrm{N}=300$ & & &
\end{tabular}

Sumber: kajian lapangan 2019

Jadual 2 merupakan hasil ujian Anova yang digunakan untuk mencari perbezaan nilai min isu-isu yang dibandingkan dengan pemboleh ubah seperti umur, tahap pendidikan dan pendapatan. Ujian ini dilakukan bagi mengenal pasti adakah terdapat perbezaan signifikan terhadap penerimaan suatu isu jika dilihat daripada aspek umur, pendidikan dan pendapatan. Hasil ujian Anova menunjukkan bahawa umur, tahap pendidikan dan pendapatan responden memberi kesan yang signifikan terhadap penerimaan suatu isu yang ditimbulkan. Berdasarkan Jadual 2, analisis berasaskan umur menunjukkan bahawa kenaikan kos sara hidup memberi kesan yang tinggi, namun, jika dilihat daripada aspek pendidikan, kejatuhan harga komoditi pertanian menjadi isu yang utama, manakala daripada sudut pendapatan pula menunjukkan isu berkaitan urus tadbir negara merupakan isu yang paling utama. Hasil analisis menunjukkan urus tadbir juga menjadi pilihan utama responden kajian ini. Urus tadbir yang baik mempunyai kaitan yang signifikan dengan kos sara hidup. Ketidakcekapan mengurus negara memberi kesan terhadap keupayaan mengurus ekonomi dengan baik dan memberi kesan terhadap pengurusan komoditi seperti Sawit dan Getah yang menjadi punca pendapatan pengundi di kawasan kajian. Berdasarkan kepada jadual tersebut perbezaan dan juga persamaan berasaskan kedudukan isu. Bagi kedudukan pertama dan kedua, didapati mempunyai perbezaan yang ketara. Terdapat persamaan kecenderungan penerimaan isu, iaitu keistimewaan Melayu, begitu juga pada kedudukan kelima, isu penarikan subsidi bagi dimensi umur dan pendidikan. Didapati pada kedudukan keenam juga memperlihatkan persamaan kecenderungan bagi dimensi umur dan pendidikan. Persamaan juga dapat dilihat pada kedudukan isu ketujuh, iaitu melibatkan kejatuhan komoditi pertanian bagi dimensi umur dan pendapatan. Selain daripada itu, terdapat perbezaan yang ketara dalam aspek kecenderungan penerimaan isu dalam kempen. Bagaimanapun dalam aspek persamaan itu juga terdapat perbezaan yang ketara pada pada nilai $F$ setiap isu. Ini menunjukkan terdapat perbezaan darjah penerimaan yang berbeza-beza antara setiap dimensi umur, pendidikan dan perolehan pendapatan. Oleh itu boleh disimpulkan bahawa penerimaan suatu isu dalam kempen pilihan raya sebenarnya berkait rapat dengan faktor-faktor latar belakang dan profil seseorang. 
Jadual 2. Perbezaan kedudukan isu berasaskan ujian Anova (perbezaan min)

\begin{tabular}{|c|c|c|c|}
\hline $\begin{array}{c}\text { Kedudukan } \\
\text { Isu }\end{array}$ & $\begin{array}{c}\text { Keputusan Ujian Anova } \\
\text { Sehala (Umur) }\end{array}$ & $\begin{array}{c}\text { Keputusan Ujian Anova } \\
\text { Sehala (Pendidikan) }\end{array}$ & $\begin{array}{l}\text { Keputusan Ujian Anova } \\
\text { Sehala (Pendapatan) }\end{array}$ \\
\hline 1 & $\begin{array}{c}\text { Kenaikan kos sara hidup } \\
\mathrm{F}(\mathrm{df}=34,265 \\
\mathrm{P}<.05)=47.189\end{array}$ & $\begin{array}{c}\text { Kejatuhan komoditi } \\
\text { pertanian } \\
\mathrm{F}(\mathrm{df}=7,292, \mathrm{P}<.05)=111.258\end{array}$ & $\begin{array}{c}\text { Isu urus tadbir negara } \\
\mathrm{F}(\mathrm{df}=21,235, \mathrm{P}<.05)=79.989\end{array}$ \\
\hline 2 & $\begin{array}{c}\text { Kedaulatan Islam } \\
\mathrm{F}(\mathrm{df}=34,265 \\
\mathrm{P}<.05)=46.058\end{array}$ & $\begin{array}{c}\text { Kemuliaan raja-raja } \\
\mathrm{F}(\mathrm{df}=7,292, \mathrm{P}<.05)=92.939\end{array}$ & $\begin{array}{c}\text { Kenaikan kos sara hidup } \\
\mathrm{F}(\mathrm{df}=21,235, \mathrm{P}<.05)=66.302\end{array}$ \\
\hline 3 & $\begin{array}{c}\text { Keistimewaan Melayu } \\
\mathrm{F}(\mathrm{df}=34,265 \\
\mathrm{P}<.05)=37.264\end{array}$ & $\begin{array}{c}\text { Isu 1MDB } \\
\mathrm{F}(\mathrm{df}=7,292, \mathrm{P}<.05)=58.154\end{array}$ & $\begin{array}{c}\text { Keistimewaan Melayu } \\
\mathrm{F}(\mathrm{df}=21,235, \mathrm{P}<.05)=63.929\end{array}$ \\
\hline 4 & $\begin{array}{c}\text { Isu urus tadbir negara } \\
\mathrm{F}(\mathrm{df}=34,265 \\
\mathrm{P}<.05)=27.387\end{array}$ & $\begin{array}{c}\text { Pengukuhan Melayu } \\
\mathrm{F}(\mathrm{df}=7,292, \mathrm{P}<.05)=47.647\end{array}$ & $\begin{array}{c}\text { Kedaulatan islam } \\
\mathrm{F}(\mathrm{df}=21,235, \mathrm{P}<.05)=60.140\end{array}$ \\
\hline 5 & $\begin{array}{c}\text { Tarik subsidi } \\
\mathrm{F}(\mathrm{df}=34,265 \\
\mathrm{P}<.05)=18.171\end{array}$ & $\begin{array}{c}\text { Tarik subsidi } \\
\mathrm{F}(\mathrm{df}=7,292, \mathrm{P}<.05)=35.135\end{array}$ & $\begin{array}{c}\text { Pengukuhan Melayu } \\
\mathrm{F}(\mathrm{df}=21,235, \mathrm{P}<.05)=51.929\end{array}$ \\
\hline 6 & $\begin{array}{c}\text { Kenaikan kos bahan api } \\
\mathrm{F}(\mathrm{df}=34,265 \\
\mathrm{P}<.05)=17.370\end{array}$ & $\begin{array}{c}\text { Kenaikan kos bahan api } \\
\mathrm{F}(\mathrm{df}=7,292, \mathrm{P}<.05)=35.055\end{array}$ & $\begin{array}{c}\text { Tarik subsidi } \\
\mathrm{F}(\mathrm{df}=21,235, \mathrm{P}<.05)=34.333\end{array}$ \\
\hline 7 & $\begin{array}{c}\text { Kejatuhan komoditi } \\
\text { pertanian } \\
\mathrm{F}(\mathrm{df}=34,265 \\
\mathrm{P}<.05)=15.280\end{array}$ & $\begin{array}{c}\text { Keistimewaan Melayu } \\
\mathrm{F}(\mathrm{df}=7,292, \mathrm{P}<.05)=34.325\end{array}$ & $\begin{array}{l}\text { Kejatuhan komoditi pertanian } \\
\mathrm{F}(\mathrm{df}=21,235, \mathrm{P}<.05)=14.655\end{array}$ \\
\hline 8 & $\begin{array}{c}\text { Isu 1MDB } \\
\mathrm{F}(\mathrm{df}=34,265 \\
\mathrm{P}<.05)=15.252\end{array}$ & $\begin{array}{c}\text { Kenaikan kos sara hidup } \\
\mathrm{F}(\mathrm{df}=7,292, \mathrm{P}<.05)=32.997\end{array}$ & $\begin{array}{c}\text { Kenaikan kos bahan api } \\
\mathrm{F}(\mathrm{df}=21,235, \mathrm{P}<.05)=14.259\end{array}$ \\
\hline 9 & $\begin{array}{c}\text { Kemuliaan raja-raja } \\
\mathrm{F}(\mathrm{df}=34,265 \\
\mathrm{P}<.05)=14.952\end{array}$ & $\begin{array}{c}\text { Kedaulatan Islam } \\
\mathrm{F}(\mathrm{df}=7,292, \mathrm{P}<.05)=25.487\end{array}$ & $\begin{array}{c}\text { Isu } 1 \mathrm{MDB} \\
\mathrm{F}(\mathrm{df}=21,235, \mathrm{P}<.05)=13.128\end{array}$ \\
\hline 10 & $\begin{array}{c}\text { Pengukuhan Melayu } \\
\mathrm{F}(\mathrm{df}=34,265, \mathrm{P}<.05)=9.107 \\
\end{array}$ & $\begin{array}{c}\text { Isu urus tadbir negara } \\
\mathrm{F}(\mathrm{df}=7,292, \mathrm{P}<.05)=24.958 \\
\end{array}$ & $\begin{array}{c}\text { Kemuliaan raja-raja } \\
\mathrm{F}(\mathrm{df}=21,235, \mathrm{P}<.05)=12.234\end{array}$ \\
\hline
\end{tabular}

Signifikan pada aras .05 ( $\mathrm{p}<.05)$

Sumber: Kajian lapangan 2019

Rajah 1 hingga Rajah 10 merupakan graf plot hasil daripada ujian Avona ke atas isuisu dalam kempen pilihan raya mengikut dimensi umur, tahap pendidikan dan pendapatan responden. Graf plot menunjukkan pola skor min berdasarkan kategori umur, tahap pendidikan dan perolehan pendapatan. Rajah 1 ialah perbezaan graf plot penerimaan isu urus tadbir negara mengikut dimensi umur, pendidikan dan pendapatan. Graf plot umur menunjukkan kategori umur 25 hingga 47 tahun tidak begitu konsisten dalam aspek penerimaan isu ini. Kategori responden berumur 25 tahun rata-ratanya menerima isu ini sebagai isu yang sederhana, manakala responden dalam kategori 55 tahun tidak menerima isu urus tadbir sebagai isu yang besar. Bagi dimensi tahap pendidikan pula, responden yang memiliki sijil kemahiran tidak melihat isu urus tadbir sebagai isu yang besar, tetapi keadaan tersebut sangat berbeza kepada kumpulan responden yang lain. Pola min penerimaan dalam dimensi pendapatan menunjukkan keadaan graf yang pelbagai, tetapi masih dalam peringkat yang tinggi kecuali begitu rendah pada kumpulan responden yang berpendapatan RM2000.

Rajah 2 ialah perbezaan graf plot penerimaan isu urus kenaikan kos sara hidup mengikut dimensi umur, pendidikan dan pendapatan. Graf plot umur menunjukkan kategori umur 55 tahun mempunyai min yang rendah. Gambaran ini menunjukkan bahawa responden berumur 55 tahun tidak memikirkan isu kenaikan kos sara hidup sebagai isu yang besar bagi mereka. Graf plot juga menunjukkan bahawa kumpulan yang berumur 25 hingga 45 tahun mempunyai darjah penerimaan yang tidak tetap perbanding kategori umur 56 hingga 84 
tahun. Situasi ini menunjukkan bahawa kategori 25 hingga 54 tahun dibebani oleh sumber pendapatan yang tidak konsisten atau mengalami tuntutan kehendak kehidupan.

Bagi dimensi tahap pendidikan pula, kumpulan yang tidak memiliki kelulusan, hanya memiliki PMR/SRP/SPM memandang isu kenaikan sebagai isu yang besar. Tetapi kumpulan responden yang memiliki sijil kemahiran, mereka tidak memilih kenaikan kos sebgai isu yang besar. Manakala kumpulan yang memiliki ijazah dan ijazah tinggi pula mempunyai pola penerimaan yang pelbagai darjah penerimaannya. Dimensi pendapatan pula menunjukkan pola penerimaan isu ini sebagai isu yang utama kecuali kepada kumpulan responden yang berpendapatan RM2000. Terdapat pola yang rendah pada dimensi umur, iaitu 55 tahun mengikut dimensi pendidikan pada tahap sijil kemahiran dan pada dimensi pendapatan.

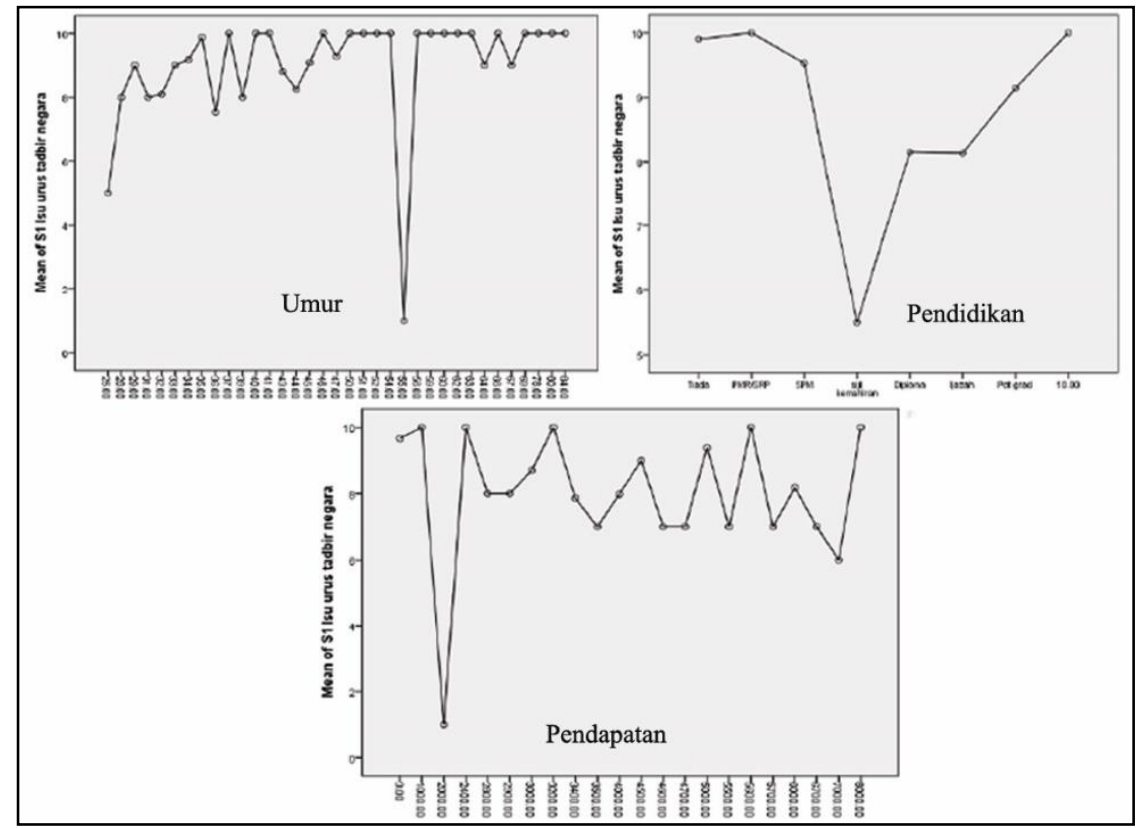

Sumber: Kajian lapangan 2019

Rajah 1. Graf plot penerimaan isu urus tadbir negara daripada dimensi umur, pendidikan dan pendapatan

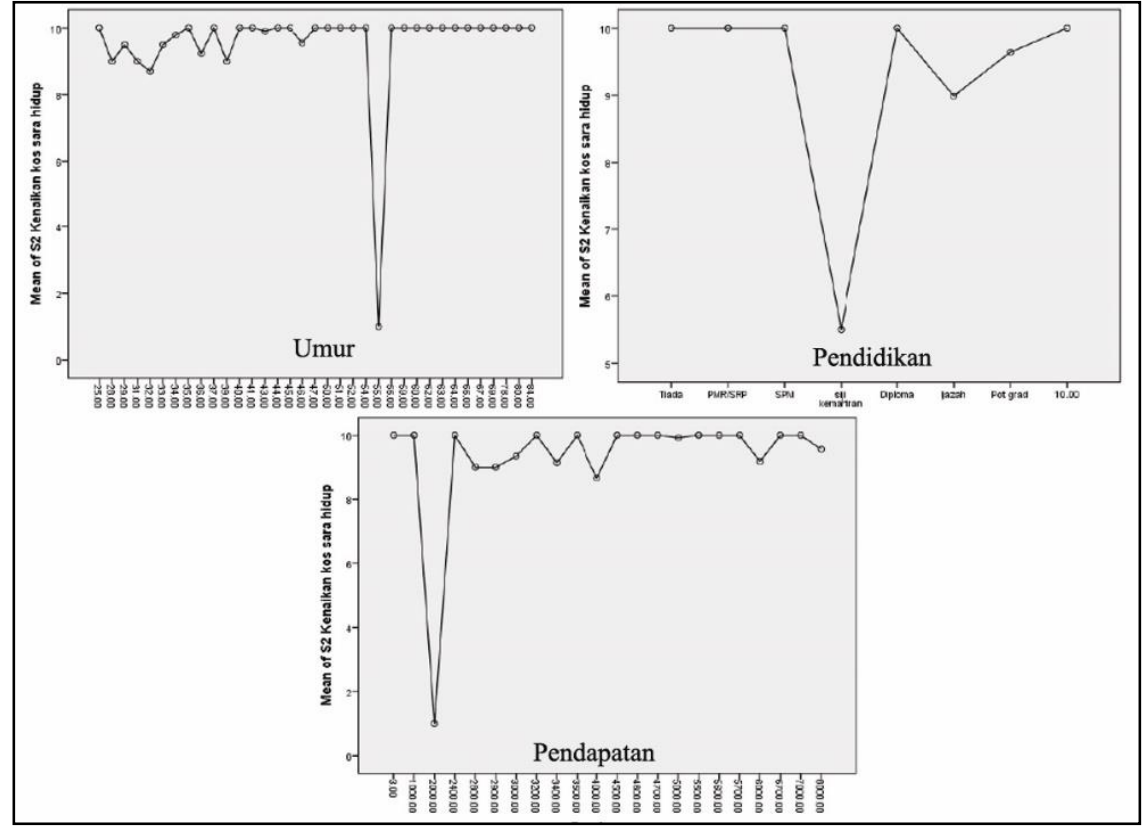

Sumber: Kajian lapangan 2019

Rajah 2. Graf plot penerimaan isu kenaikan kos sara hidup daripada dimensi umur, pendidikan dan pendapatan 
Rajah 3 ialah perbezaan graf plot penerimaan isu pengukuhan Melayu mengikut dimensi umur, pendidikan dan pendapatan. Graf plot umur menunjukkan kategori umur 55 tahun mempunyai min yang rendah. Gambaran ini menunjukkan bahawa responden yang berumur 55 tahun tidak memikirkan isu pengukuhan Melayu sebagai isu yang besar bagi mereka. Graf plot juga menunjukkan bahawa kumpulan yang berumur 25 hingga 63 tahun mempunyai darjah penerimaan yang tidak tetap berbanding dengan kategori umur 65 hingga 84 tahun. Situasi ini menunjukkan bahawa kategori 25 hingga 63 tahun memandang isu pengukuhan Melayu sebagai isu yang penting.

Bagi dimensi tahap pendidikan pula, kumpulan yang tidak memiliki kelulusan, iaitu yang hanya memiliki PMR/SRP/SPM memandang isu penyatuan Melayu sebagai isu yang besar. Tetapi kumpulan responden yang memiliki sijil kemahiran, tidak merasakan isu pengukuhan Melayu sebagai isu yang besar. Manakala kumpulan yang memiliki ijazah dan ijazah tinggi pula mempunyai pola penerimaan yang pelbagai darjah penerimaannya. Dimensi pendapatan pula menunjukkan pola penerimaan isu ini sebagai isu yang utama kecuali kepada kumpulan responden yang berpendapatan RM2000. Terdapat pola yang rendah pada dimensi umur iaitu 55 tahun, dimensi pendidikan pada tahap sijil kemahiran dan pada dimensi pendapatan.

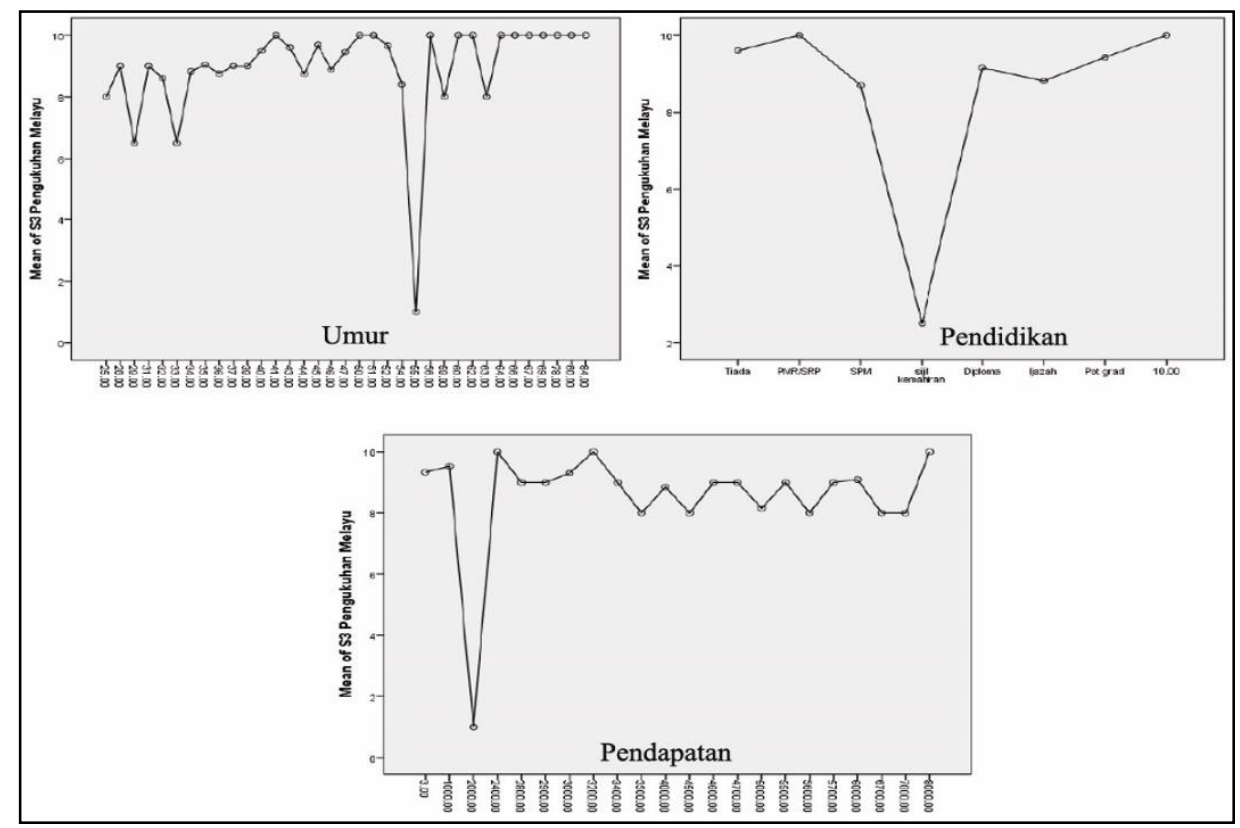

Sumber: Kajian lapangan 2019

Rajah 3. Graf plot penerimaan isu pengukuhan Melayu daripada dimensi umur, pendidikan dan pendapatan

Rajah 4 ialah graf plot berkaitan dengan isu keistimewaan Melayu. Dalam aspek dimensi umur, kumpulan responden berumur 25 hingga 84 tahun meletakkan nilai pilihan antara 8 hingga 10 mata bagi isu keistimewaan Melayu. Begitu juga bagi dimensi pendidikan dan juga dimensi perolehan pendapatan. Kelihatan pola yang dihasilkan menunjukkan persamaan, tetapi tetap berbeza dalam aspek darjah penerimaan pada setiap kategori berbeza. Konsistensi terhadap isu ini dapat dilihat pada dimensi umur, iaitu responden berumur 64 hingga 84 tahun mempunyai tahap penerimaan isu dengan konsisten.

Rajah 5 ialah perbezaan graf plot penerimaan isu kedaulatan Islam mengikut dimensi umur, pendidikan dan pendapatan. Graf plot umur menunjukkan responden berumur 25 hingga 45 tahun tidak konsisten penerimaan isu kedaulatan Islam sebagai suatu isu besar. Namun pola yang begitu konsisten dapat dilihat pada umur 45 hingga 54 tahun dan 56 hingga 84 tahun. Gambaran ini menunjukkan bahawa peningkatan umur kepada responden 
mempunyai kaitan yang signifikan kepada isu kedaulatan Islam. Bagi graf plot pendidikan pula, menunjukkan responden yang tidak memiliki kelulusan dan yang memiliki kelulusan mempunyai tahap penerimaan isu yang berbeza darjahnya. Didapati kumpulan responden yang memiliki ijazah tinggi, darjah penerimaannya agak rendah berbanding dengan kategori lain, kecuali dengan mereka yang memiliki sijil kemahiran. Pola yang berbeza dapat dilihat ke atas graf plot dimensi tahap pendapatan yang tidak menunjukkan konsistensi terhadap darjah penerimaannya, walaupun penerimaan terhadap isu ini agak tinggi.

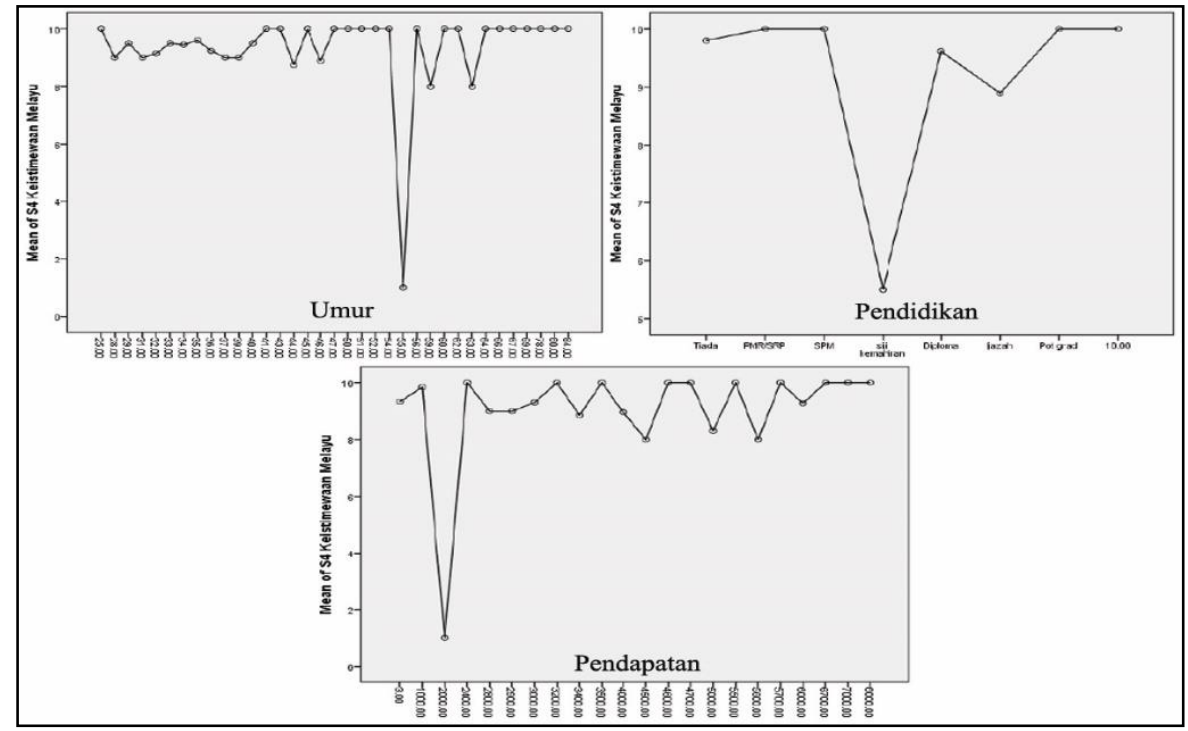

Sumber: Kajian lapangan 2019

Rajah 4. Graf plot penerimaan isu keistimewaan Melayu daripada dimensi umur, pendidikan dan pendapatan

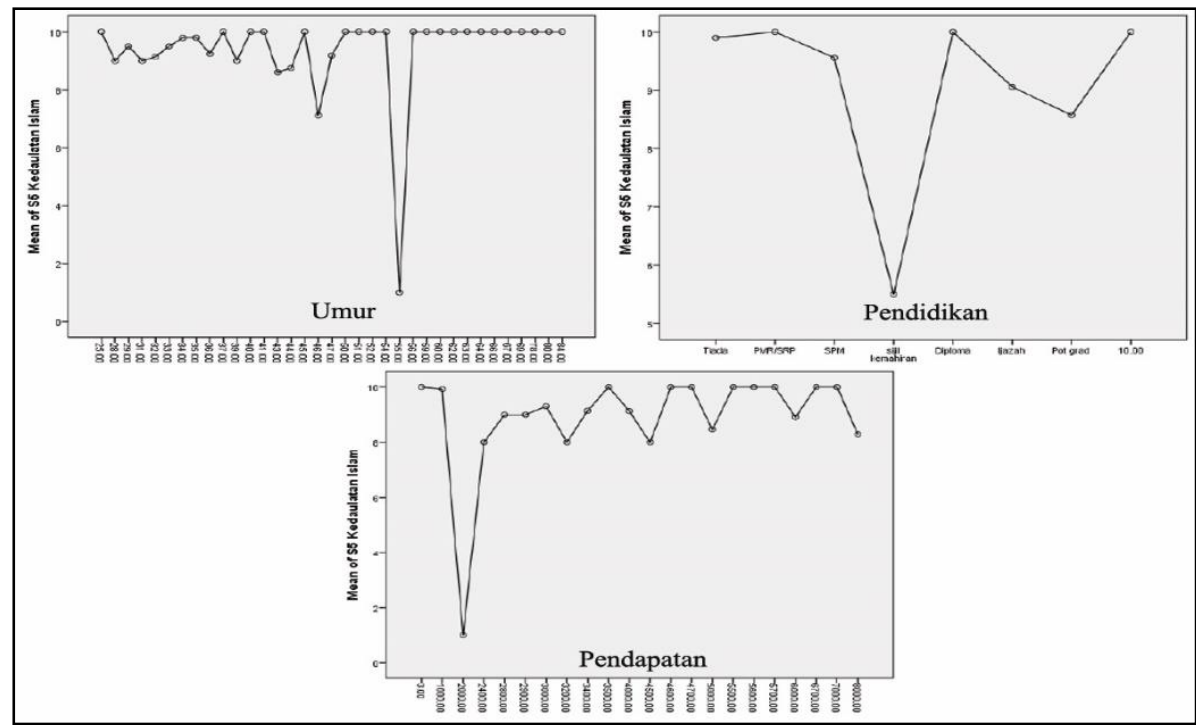

Sumber: Kajian lapangan 2019

Rajah 5. Graf plot penerimaan isu kedaulatan Islam daripada dimensi umur, pendidikan dan pendapatan

Rajah 6 ialah perbezaan graf plot penerimaan isu kenaikan kos bahan api mengikut dimensi umur, pendidikan dan pendapatan. Pola graf plot umur menunjukkan terdapat jurang perbezaan yang begitu ketara jaraknya. Kumpulan umur 25 hingga 54 tahun menerima isu ini sebagai isu yang besar, Namum bagi kategori responden berumur 56 hingga 84 tahun dilihat bercampur-campur. Ada kumpulan yang menganggap isu ini besar dan ada yang melihat isu ini sebagai isu sederhana. Berlainan pula graf plot bagi dimensi pendapatan, kumpulan yang 
mempunyai pendapatan tinggi tidak merasakan kenaikan kos bahan api sebagai isu yang besar, berbanding kumpulan yang mempunyai pendapatan rendah. Boleh disimpulkan bahawa kumpulan responden yang muda atau masih bekerja melihat isu kenaikan harga bahan api sebagai masalah yang besar.

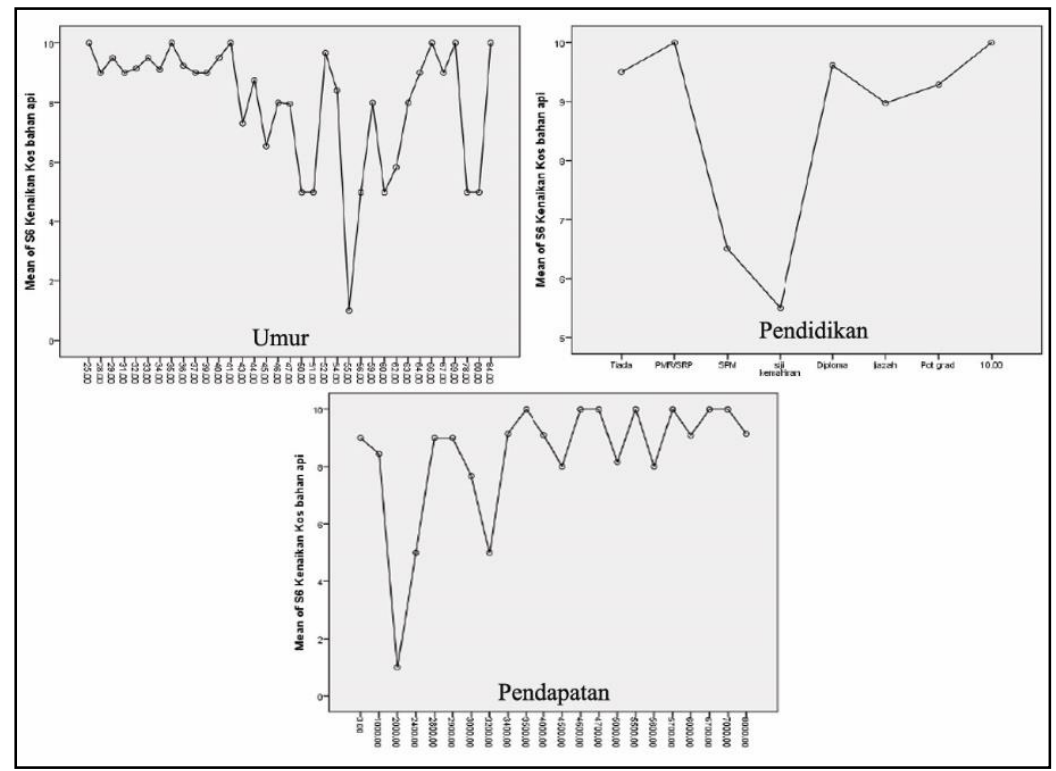

Sumber: Kajian lapangan 2019

Rajah 6. Graf plot penerimaan isu kenaikan kos bahan api daripada dimensi umur, pendidikan dan pendapatan

Rajah 7 ialah perbezaan graf plot penerimaan isu penarikan subsidi oleh kerajaan mengikut dimensi umur, pendidikan dan pendapatan. Pola graf plot umur menunjukkan majoriti responden menganggap isu ini sebagai isu yang besar. Rata-rata menerima isu ini dalam kempen pilihan raya sebagai isu yang relevan. Bagi graf plot pendidikan, kumpulan yang mempunyai sijil kemahiran seakan tidak menerima isu ini sebagai isu yang besar. Manakala bagi dimensi pendapatan didapati plot graf berlaku turun naik terhadap darjah penerimaan bergantung kepada jumlah pendapatan yang diperolehi. Boleh disimpulkan bahawa isu penarikan subsidi ini juga merupakan isu yang diterima oleh responden kajian ini.

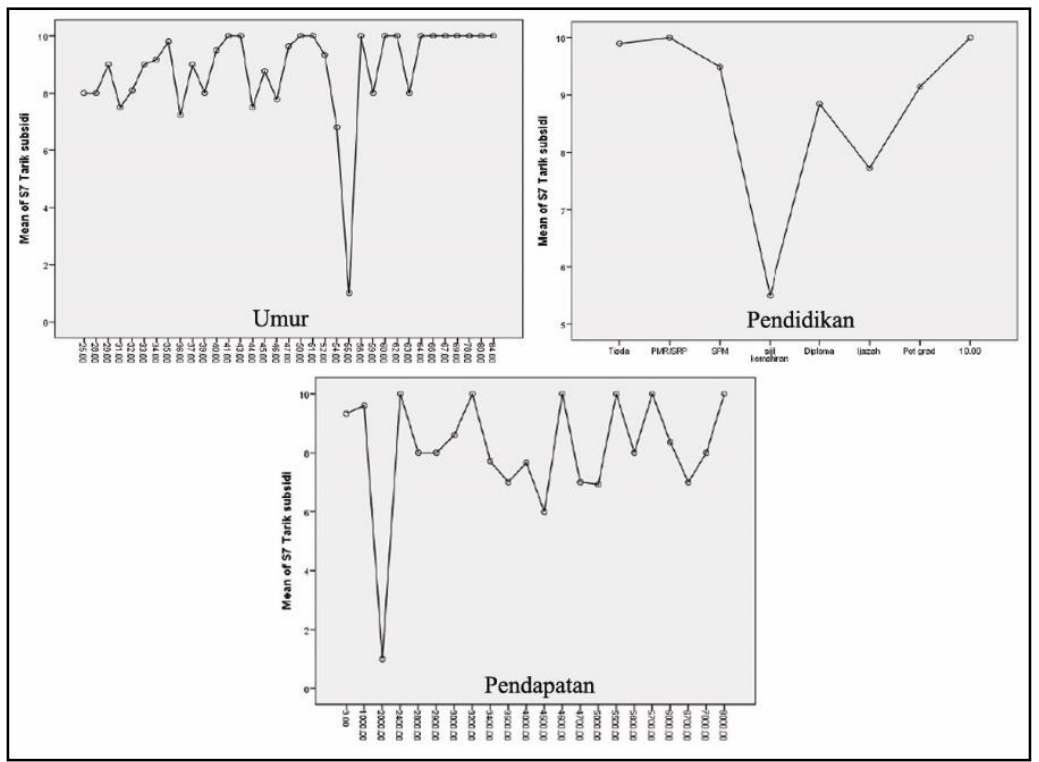

Sumber: Kajian lapangan 2019

Rajah 7. Graf plot penerimaan isu penarikan subsidi daripada dimensi umur, pendidikan dan pendapatan 
Rajah 8 ialah perbezaan graf plot penerimaan isu kemuliaan raja-raja mengikut dimensi umur, pendidikan dan pendapatan. Pola graf plot umur menunjukkan terdapat jurang yang cukup besar bagi responden berumur antara 25 hingga 64 tahun. Kumpulan yang berumur 64 hingga 84 tahun didapati lebih konsisten menerima isu kemuliaan raja-raja dalam kempen pilihan raya. Pola ini menunjukkan bahawa kumpulan responden muda dan pertengahan kurang cenderung menerima isu kemuliaan raja-raja dalam kempen pilihan raya. Begitu juga pola penerimaan bagi dimensi tahap pendidikan, kumpulan yang mempunyai kelulusan tinggi kurang menerima isu yang berkaitan dengan raja-raja Melayu. Pola yang sama juga dapat dilihat pada dimensi perolehan pendapatan. Kumpulan responden yang mempunyai pendapatan sederhana dan tinggi juga kurang menerima isu kemuliaan raja-raja dalam kempen pilihan raya.

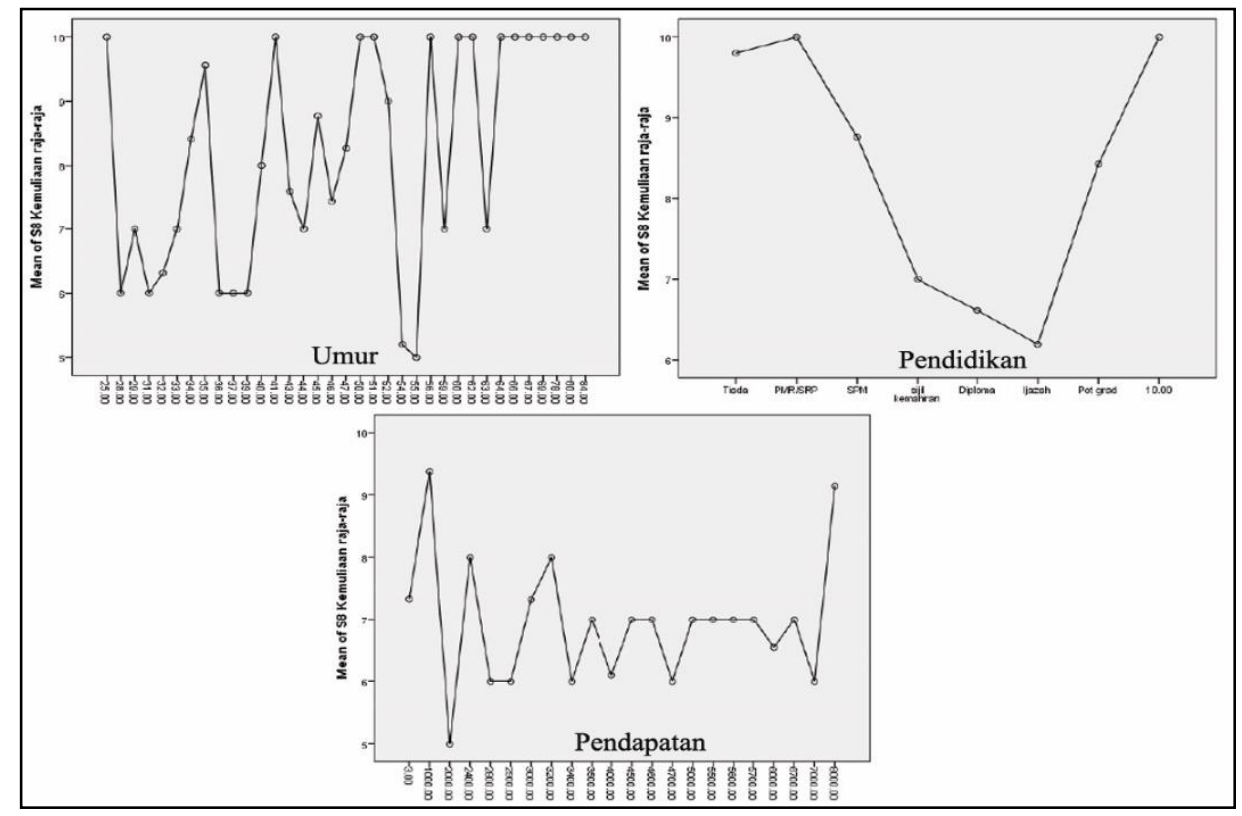

Sumber: Kajian lapangan 2019

Rajah 8. Graf plot penerimaan isu kemuliaan raja-raja daripada dimensi umur, pendidikan dan pendapatan

Rajah 9 ialah perbezaan graf plot penerimaan isu yang dikaitkan dengan 1MDB mengikut dimensi umur, pendidikan dan pendapatan. Terdapat dua pola yang berbeza pada dimensi umur. Kumpulan muda hingga pertengahan menerima isu ini dengan julat min yang tidak jauh berbeza, namum julat skor min pada kumpulan berumur agak besar. Ini menunjukkan bahawa ada sebahagian kumpulan yang menerima isu 1MDB sebagai isu yang besar dan pada masa yang sama terdapat juga kumpulan yang tidak menerima isu 1MDB sebagai isu yang besar dalam pilihan raya. Bagi dimensi pendidikan pula didapati kumpulan responden yang tidak mempunyai kelulusan akademi tidak menerima isu 1MDB sebagai isu besar. Tetapi kumpulan responden yang mempunyai kelulusan akademik menerima 1MDB sebagai isu besar dalam kempen pilihan raya. Begitu juga dalam dimensi pendapatan, ratarata responden menerima isu $1 \mathrm{MDB}$ sebagai isu yang besar dalam kempen pilihan raya. 


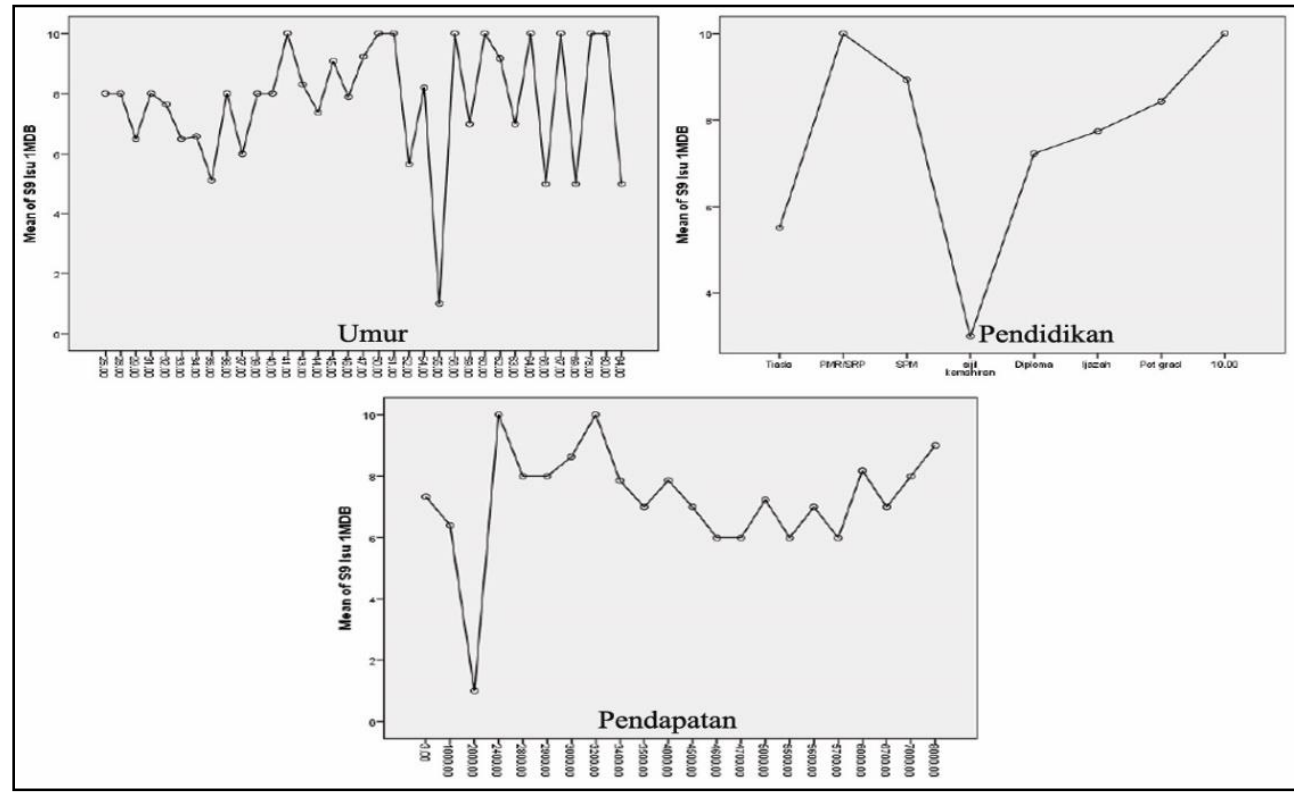

Sumber: Kajian lapangan 2019

Rajah 9. Graf plot penerimaan isu 1MDB daripada dimensi umur, pendidikan dan pendapatan

Rajah 10 ialah perbezaan graf plot penerimaan isu kejatuhan harga komonditi pertanian mengikut dimensi umur, pendidikan dan pendapatan. Berdasarkan kepada graf plot umur, terdapat julat perbezaan agak besar, tetapi mengecil semula bermula pada umur 56 tahun. Keadaan ini menunjukkan kumpulan yang terkesan dengan kejatuhan harga komoditi adalah kumpulan tersebut. Pola julat yang melebar juga boleh dilihat pada dimensi tahap pendidikan. Namum bagi dimensi pendidikan kumpulan yang tidak mempunyai ijazah menerima isu kejatuhan harga komoditi sebagai isu besar. Pola julat yang pelbagai juga boleh dilihat pada dimensi perolehan pendapatan. Graf plot ini menunjukkan bahawa terdapat kumpulan yang menerima isu kejatuhan harga komoditi sebagai isu, dan ada juga yang tidak menerimanya sebagai isu yang besar.

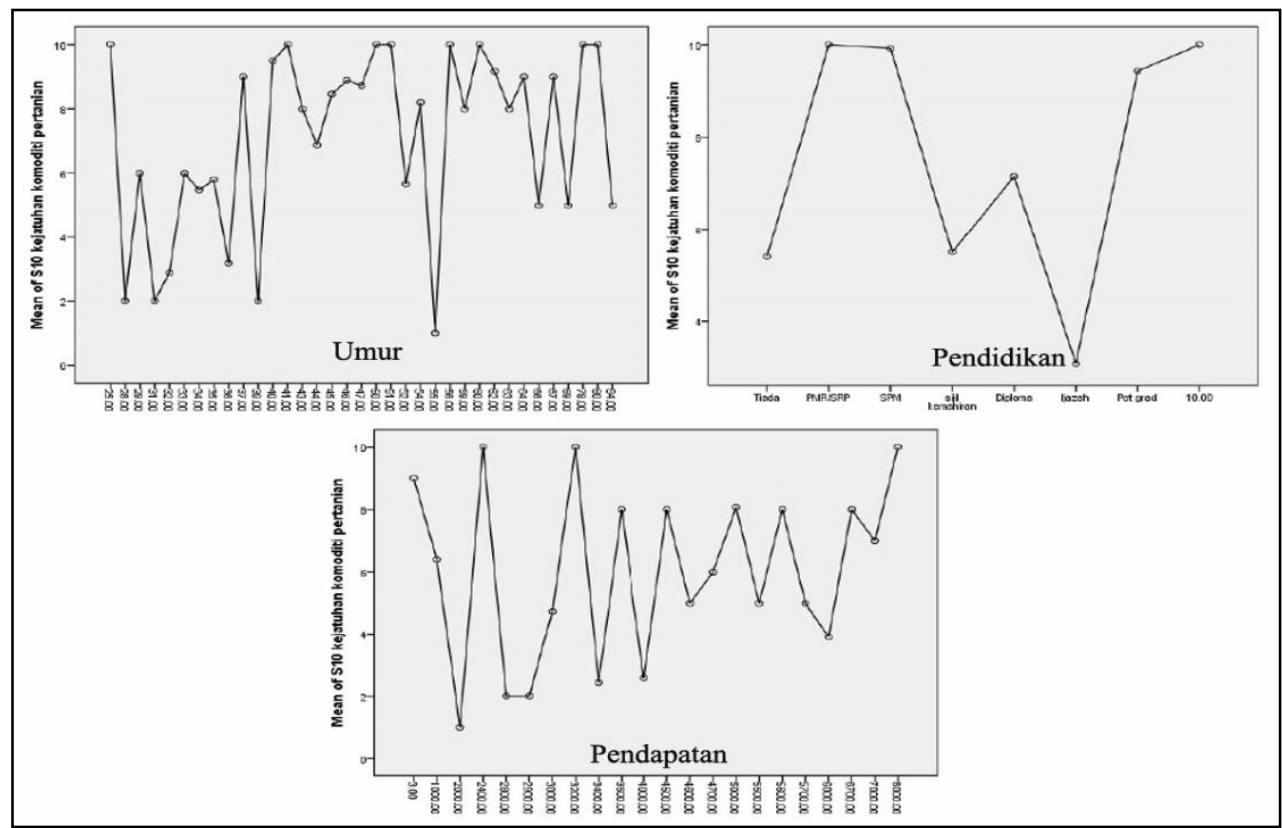

Sumber: Kajian lapangan 2019

Rajah 10. Graf plot penerimaan isu kejatuhan harga komoditi daripada dimensi umur, pendidikan dan pendapatan 


\section{Perbincangan}

Analisis secara makro ke atas maklumat yang diberikan oleh responden kajian ini pada dasarnya menunjukkan bahawa sepuluh isu yang dikaitkan orang Melayu, diterima sebagai isu yang mendapat perhatian mereka. Dapatan daripada Jadual 1 menunjukkan dengan jelas bahawa kesemua isu diterima dengan skor min melebihi nilai sederhana [5]. Bagaimanapun, apabila analisis anova dilakukan mengikut pemboleh ubah seperti umur, tahap pendidikan dan perolehan pendapatan, telah memberikan maklumat yang berbeza berbanding dengan analisis secara umum. Bagaimana pun, analisis yang dibuat secara umum tersebut, tidaklah boleh diketepikan begitu sahaja. Dapatan tersebut masih boleh digunakan bagi menggambarkan penerimaan sesuatu isu oleh orang Melayu secara keseluruhannya.

Perlu diperjelaskan bahawa penerimaan isu yang berkaitan dengan Melayu sebenarnya adalah berdasarkan kepada beberapa faktor seperti umur, tahap pendidikan dan juga taraf sosio-ekonomi seseorang. Tidak semua isu mendapat perhatian semua orang, kerana keperluan dan kehendak setiap individu adalah berbeza. Dalam konteks ini terdapat beberapa isu yang melibatkan semua kumpulan, sebagai contohnya isu kenaikan kos bahan api, kos sara hidup dan penarikan semula subsidi. Boleh dikatakan kenaikan kos kenaikan bahan api, penarikan subsidi dan sara hidup adalah isu yang sama tetapi dalam dimensi berbeza. Kenaikan kos bahan api dan penarikan semula subsidi menjadi penyebab kepada kenaikan sesetengah barangan pengguna. Walaupun penghapusan subsidi boleh meningkatkan prestasi makro-ekonomi dan fiskal negara serta membawa kepada mengurangkan penggunaan tenaga yang seterusnya mengurangkan pelepasan bahan cemar, tetapi masyarakat pengguna yang berpendapatan rendah menerima kesan langsung akibat kenaikan harga. Isi rumah terpaksamenanggung kenaikan kos tenaga yang mereka gunakan. Manakala pengguna pertengahan (kilang, pengangkutan, dan sebagainya) juga turut menghadapi kenaikan kos yang lebih tinggi. Akhir sekali, sebahagian besar beban kenaikan ini akan dilepaskan kepada pengguna akhir. Akibat daripada itu, kesan tersebut akan diterima oleh semua orang tanpa mengira etnik.

Isu urus tadbir negara pula, dalam konteks sebagai isu kepada Melayu sebenarnya tidak menjadi perkara yang bersifat langsung. Perkara ini menjadi isu apabila kesan kepada rakyat terutamanya orang Melayu bila ianya melibatkan peningkatan perbelanjaan isu rumah. Peningkatan kos bahan api, kos sara hidup, penurunan harga komoditi (yang menjadi punca pendapatan golongan petani-terutamanya Melayu) dan juga rasionalisasi subsidi telah mengurangkan kemampuan rakyat bagi menjalani kehidupan sempurna. Apabila perkara ini terjadi, orang Melayu akan mempersoalkan kemampuan kerajaan mengurus tadbir negara. Timbul pula isu yang berkaitan pembelaan nasib orang Melayu, adakah kerajaan membiarkan orang Melayu tanpa pembelaan. Sedangkan perkara yang sama turut dihadapi oleh etnik lain, namum sentimen kemelayuan digunakan oleh pihak parti politik untuk meraih sokongan pengundi. Justeru, pemilihan responden kajian terhadap isu melibatkan perkara yang mempunyai kaitan dengan ekonomi mereka walaupun pada masa yang sama turut melihat isu yang bersifat sentimen, iaitu isu Melayu-Islam.

Isu pengukuhan Melayu, kedaulatan Islam, kemuliaan raja-raja adalah isu yang diterima dalam kempen pilihan raya. Namun, terdapat kumpulan yang memandang perkara ini bukan sebagai isu yang besar terutamanya oleh kumpulan yang mempunyai pendidikan dan perolehan pendapatan yang sederhana dan tinggi. Perkara ini menjadi isu apabila dikaitkan dengan sentimen etnisiti dan agama. Tidak dapat dinafikan bahawa orang Melayu mempunyai sentimen yang kuat terhadap isu Melayu-Islam. Berdasarkan kepada dapatan yang diperolehi, boleh di penyatuan Melayu bukan agenda utama pengundi. Jelas penyatuan Melayu yang dijadikan isu merupakan agenda parti politik UMNO-PAS. Penyatuan MelayuIslam sebenarnya boleh melampaui agenda politik. Apa-apa yang dikaitkan dengan Melayu- 
Islam akan menarik minat mereka dan boleh membangkitkan semangat untuk membela agama dan bangsa (Ahmad Munawar et al., 2012).

Kedudukan isu yang menjadi pilihan dalam pilihan raya jelas mempelihatkan pilihan rasional dalam kehidupan sosial mereka. Pilihan orang Melayu ini jelas memperlihatkan jati diri Melayu pinggir Bandar secara keseluruhannya. Pilihan yang dibuat berdasarkan faedah yang diperolehi melibatkan ekonomi yang memberi kesejahteraan dalam kehidupan. Pada masa yang sama, mereka masih mempunyai pegangan kuat terhadap sentimen Melayu-Islam. Setiap perkara yang menjadi budaya dalam kehidupan mesti dihubungkait dengan Islam.

\section{Rumusan}

Isu-isu Melayu-Islam merupakan isu yang secara keseluruhannya akan menarik penerimaan orang Melayu dalam kempen pilihan raya. Sentimen orang Melayu terhadap perkara yang melibatkan Melayu-Islam menjadi prasyarat penerimaan mereka, terutamanya orang Melayu yang tinggal di pinggir bandar. Ini adalah kerana jadi diri dan pusat tumpuan nilai sejagat bagi orang Melayu itu sendiri tidak boleh dipisahkan dengan perkara tersebut. Dalam konteks kajian ini, boleh dirumuskan bahawa isu sejagat seperti kenaikan kos sara hidup dan sentimen Melayu-Islam diterima oleh orang Melayu berasaskan kepentingan sosio-budaya dan kepentingan individu. Ini bermakna penerimaan sesuatu isu dalam kempen pilihan raya adalah bergantung kepada kesan dan faedah yang diterima oleh mereka. Dalam menentukan pilihan politik orang Melayu secara jelas menitik beratkan dua perkara utama. Perkara yang pertama ialah kebaikkan yang bersifat praktikal iaitu melibatkan ekonomi yang memberi kesan terhadap kehidupan mereka. Persoalan ekonomi ini berpaksikan kepada urus tadbir yang baik, yang mana urus tadbir yang baik ini memberi kesan yang positif terhadap penjanaan ekomoni. Dalam konteks penduduk pinggir bandar, keboleh pasaran komoditi sSawit dan getah menjadi sumber pendapatan utama. Perkara kedua, orang Melayu tidak meminggirkan sentimen Melayu-Islam. Islam telah menjadi tunggak budaya masyarakat Melayu. Ini bermakna Melayu tidak menolak sama sekali pemodenan, namum Islam harus menjadi elemen utama pada setiap perkara yang diperkenalkan kepada orang Melayu.

\section{Rujukan}

Abu Sufian Abu Bakar. (2018). Impak reformasi subsidi bahan api di Malaysia. 5th Annual ECoFI Symposium, Universiti Utara Malaysia, Sintok, Kedah, Malaysia.

Ahmad Munawar Ismail, Zakaria Stapa \& Siti Aishah Suhaimi. (2012). Islam dan pembentukan jati diri bangsa Melayu. Jurnal Hadhari, Special Edition (2012), 143154.

Amanah. (2017). Sejarah penubuhan AMANAH. Diperoleh daripada: https://amanah.org. my/sejarah/

Asmadi Hassan, Rohayati Paidi \& Muhammad Danial Azman. (2019). Jepun Vs Malaysia: Strategi kempen Pilihan Raya Umum 2017 dan 2018. Jebat: Malaysian Journal of History, Politics \& Strategic Studies, 46(1), 172-195.

Asyraf Wajdi. (2019). Timbang semula dasar baharu subsidi rayuan haji kali pertama. Diperoleh daripada: http://www.astroawani.com/berita-malaysia/timbang-semuladasar-baharu-subsidi-rayuan-haji-kali-pertama-asyraf-wajdi-198696

Coleman, R., Liber, P., Mendelson, L., \& Kurpius, D. (2008). Public life and the internet: If you build a better website will the citizens become engaged. New Media and Society, 10(2), 179-201. 
Graber, D. (2003). The media and democracy: Beyond myths and stereotypes. Annual Review of Political Science, 6, 139-160.

Hasnah Hussiin. (2009). Kesan modenisasi ke atas hubungan kaum di Malaysia. Jurnal UMP Sains Sosial \& Pengurusan Teknologi, 1(1), 13-22.

Ismail Bin Said, 2008). Parti Islam Sa-Malaysia: Kepimpinan dan Perjuangan dari Tahun 1951 Hingga 1970 (Tesis Phd). Diperoleh daripada Pusat Pengajian Pendidikan Jarak Jauh, Universiti Sains Malaysia.

Junaidi Awang Besar, Mohd Fuad Mat Jali \& Novel Lyndon. (2012b). Pengaruh Populariti Calon, Sentimen Nasional dan PolitikPembangunan dalam Pilihan Raya Kecil (PRK) P185 Batu Sapi, Sabah. Geografia-Malaysia Journal of Society and Space, 8(8), 2334.

Junaidi Awang Besar, Mohd Fuad MatJali, Yahaya Ibrahim, Abdul Halim Sidek, Jeniri Amir, Rosmadi Fauzi \& Novel Lyndon. (2012a). Persepsi politik pengundi belia Melayu pasca Pilihan Raya Umum (PRU) 2008 di Malaysia. Jurnal Melayu, 9(2012), 191-214.

Ku Hasnan Bin Ku Halim, Ainudin Lee Bin Iskandar Lee \& Suhaimi Bin Sulaiman. (2012). UMNO dan krisis; Penelitian kepada krisis dalaman-kes terpilih. Juarnal of Techno Social, 4(2), 103-115.

Lee Kuok Tiung, Rizal Zamani Idris \& Rafiq Idris. (2018). Propaganda dan disinformasi: Politik persepsi dalam Pilihan Raya Umum Ke-14 (Pru-14) Malaysia. Jurnal Kinabalu, (Khas), 1-20.

Mohd Azri Ibrahim, Muhammad Shamshinor Abdul Azzis, Mohd Azmir Mohd Nizah, Afi Roshezry Abu Bakar \& Mohammad Tawfik Yaakub. (2016). Analisis isu dominan dalam Pilihanraya Kecil DUN Sungai Limau. Prosiding Persidangan Pemantapan Citra Kenegaraan 4 (COSNA 4), Kampus Sultan Azlan Shah, 503-514.

Mohd Faidz Mohd Zain, Jamaie Hj. Hamil, Mohd Rizal Mohd Yaakob \& Mohamad Rodzi Abd Razak. (2011). Pengaruh nasionalisme Melayu mewarnai budaya politik Melayu dalam UMNO. Jurnal Melayu, 7(2011), 193-216.

Mohd Shazwan Mokhtar, Muhammad Aslah Akmal Azmi \& Suffian Mansor. (2019). Sejarah perkembangan Majlis Raja-Raja Melayu. Prosiding Seminar 120 Tahun Majlis RajaRaja Melayu, UKM, Bangi.

Muhamad Nadzri Mohamed \& Noorjamaie Hj. Hamil, 2018. Politik, pengundi dan faktor Melayu/Bumiputera: Analisis terhadap kegagalan Barisan Nasional dalam PRU 2018. Jebat: Malaysian Journal of History, Politics \& Strategic Studies, 45(2), 386-408.

Muhammad Hazim Abdul Ghani, Junaidi Awang Besar \& Mohd Fuad Mat Jali. (2016). Isu dasar kerajaan dalam politik pengundi pasca pilihan raya: Kajian kes DUN Teratai, Pandan, Selangor Darul Ehsan. Geografia-Malaysian Journal of Society and Space, 12(4), 34-45.

PPBM. (2017). Perlembagaan Parti Pribumi Bersatu Malaysia. Diperoleh daripada: https://ppbmbersatu.blogspot.com/

Rabiatul Adawiah Saat, Iqlima Ibrahim, Nur Izzata Mohd Salleh \& Nurul Aida Zuber. (2019). Maqasid Syariah dalam urus tadbir. Proceeeding of the International Conference on Islamic Civilization and Technology Management, TATIUC \& UniSZA, Kuala Terengganu.

Ritzer, G. (2011). Sociological Theory-Eight Edition. New York: The McGrow Hill Companies.

Shamsudin A. Rahim. (2010). Media, demokrasi dan generasi muda: Analisis keputusan Pilihan Raya Umum Ke-12. Jurnal Komunikasi, Malaysian Journal of Communication, 26(2), 1-15. 
Solahuddin bin Abdul Hamid. (2016). Islam Dalam Pembentukan Pandangan Semesta Masyarakat Melayu. Jurnal Seri Alam, 1(12), 143-150.

Suhaimee Saahar. (2008). Isu-isu utama sebelum, semasa dan selepas Pru 12: Satu analisis kandungan blog-blog politik Malaysia terpilih. Jebat: Malaysian Journal of History, Politics \& Strategic Studies, 35(2008), 81-96.

SPR. (2007). 50 Tahun Demokrasi dan Pilihan Raya di Malaysia. Kuala Lumpur: Berita Publishing Sdn. Bhd.

Wan Ahmad Fauzi Wan Husain. (2017). Perkara 181(1) Perkukuh Kedaulatan Raja. Diperoleh daripada: https://www.bharian.com.my/rencana/muka10/2017/07/301952/ perkara-181-1-perkukuh-kedaulatan-raja. 